\title{
Representasi dan Stereotip pada Perempuan Berkulit Gelap dalam Iklan "Fair and Lovely"
}

\section{Ma'ruf Fathoni}

Program Studi Ilmu Komunikasi, Universitas Muhammadiyah Yogyakarta maruffat@gmail.com

\section{Della Fadillah}

Program Studi Ilmu Komunikasi, Universitas Muhammadiyah Yogyakarta dellafadillah128@gmail.com

Diserahkan: 15 Februari 2020; Direvisi: 26 Maret 2021; Diterima: 26 Maret 2021

\begin{abstract}
Advertising is a medium to promote a product or brand. Many advertisers are competing to find ways to attract buyers so that their goods are purchased by the public. Women and beauty are two things that are difficult for many people to separate. The demand to always look beautiful will always follow the female figure wherever she goes. Including beauty products, cosmetic manufacturers will constantly try to present new concepts (or old concepts that are updated) to society and women, of course, about what is called ideal beauty. Through their products, they try to provide the latest conceptualization of being beautiful. This study was designed to analyze the Fair and Lovely advertisement in 2016 which represented dark-skinned women using Roland Barthes' semiotic analysis. The analysis was carried out by looking at the signs that appeared in the advertisement images on the Fair and Lovely television media in 2016, starting from facial expressions, skin color shown in the advertisement. In this advertisement, it represents as if women who have dark skin are an ugliness, so it must be changed through glowing white skin.

Keywords: Fair and Lovely, Beauty, Women, Representation.
\end{abstract}

\begin{abstract}
Abstrak
Iklan merupakan suatu media untuk mempromosikan sebuah produk atau brand. Banyak pengiklan berlomba-lomba mencari cara untuk menarik minat pembeli agar barangnya dibeli oleh masyarakat. Perempuan dan kecantikan adalah dua hal yang bagi banyak orang sulit dipisahkan. Tuntutan untuk selalu tampil cantik akan selalu mengikuti sosok perempuan kemana pun ia pergi. Termasuk produk kecantikan, para produsen kosmetik akan terus-menerus mencoba untuk menyodorkan konsep-konsep baru (atau konsep lama yang diperbarui) kepada masyarakat dan perempuan tentunya, tentang apa itu yang dinamakan kecantikan ideal. Melalui produk-produknya, mereka berusaha untuk memberikan konseptualisasi tentang menjadi cantik yang terkini. Penelitian ini dirancang untuk menganalisis iklan Fair and Lovely pada tahun 2016 yang merepresentasikan perempuan berkulit gelap menggunakan analisis semiotika Roland Barthes. Analisis yang dilakukan yaitu dengan melihat tanda-tanda yang muncul dalam gambar iklan di media televisi Fair and Lovely tahun 2016, mulai dari ekspresi wajah, warna kulit yang ditampilkan dalam iklan tersebut. Pada iklan ini merepresentasikan seolah-olah perempuan yang memiliki kulit gelap merupakan sebuah kejelekan, maka itu harus diubah melalui kulit putih bersinar.

Kata Kunci: Fair and Lovely, Kecantikan, Perempuan, Representasi.
\end{abstract}




\section{PENDAHULUAN}

Dalam dunia yang sudah sangat berkembang seperti sekarang ini, media massa merupakan hal yang sangat penting. Apalagi dengan masuk dan merebaknya media massa digital, saluran komunikasi menjadi lebih lancar. Salah satu media massa yang dapat kita konsumsi setiap saat adalah iklan. Iklan merupakan salah satu upaya perusahaan dalam rangka mempromosikan barang maupun jasa. Dalam usaha menyebar luaskan iklan, maka dibutuhkan media massa. Dari berbagai jenis media massa yang ada, iklan televisi dinilai lebih kuat dibandingkan dengan media yang lainnya. Halini dikarenakan televisi memiliki jangkauan yang luas, fleksibel dan efektif untuk memasarkan dan mengenalkan suatu produk. Televisi adalah media mainstream yanghampir setiap masyarakat Indonesia memiliki televisi dan menonton siaran televisi sehingga dengan menggunakan tayangan iklan di televisi diharapkan produk yang ditawarkan akan diketahui oleh masyarakat luas.

Salah satu produk yang mempromosikan produknya melalui saluran televisi adalah produk sabun pencuci muka "Fair and Lovely". Berbicara mengenai perempuan dan media menjadi dua hal yang tidak bisa dipisahkan. Apalagi mengingat tayangan iklan yang mengeksploitasi perempuan dalam media televisi yang bersifat audio visual memiliki pengaruh sangat besar terhadap khalayak karena gambar yang ditayangkan terlihat hidup seolah nyata, Kita pun tidak bisa memungkiri hal ini.

Mengingat berbagai fakta yang disajikan media massa, yang mayoritas berhubungan dengan perempuan seolah-olah standar hidup manusia diukur menurut iklan. Pengaruh iklan begitu dahsyatnya sampai menjadi tuntunan, misalnya pada kulit wajah atau kulit tubuh yang lain. Salah satu iklan yang mengkonstruksi masyarakat tentang wajah adalah iklan Fair and Lovely. Iklan di media televisi yang ditampilkan oleh produk Fair and Lovely, sering memanfaatkan kaum perempuan dengan menonjolkan fisik tertentu yang bertujuan untuk daya tarik konsumen. Di dalam iklan Fair and Lovely dikatakan bahwa perempuan yang cantik adalah perempuan yang memiliki wajah putih bersinar. Perempuan yang berkulit gelap dikatakan tidak menarik. Dengan memakai Facial Wash Fair and Lovely, kulit akan menjadi putih bersinar sehingga banyak yang mendambakan. Kemudian yang menjadi soal adalah saat para perempuan yang berkulit gelap merasa tidak percaya diri karena kulit mereka tidak putih bersinar seperti yang dikatakan di dalam iklan tersebut. Hal tersebut mempengaruhi penonton televisi sehingga masyarakat akan berpikiran bahwa perempuan cantik adalah perempuan yang memiliki wajah putih bersinar.

Iklan Fair and Lovely telah diunggah ulang oleh akun Youtube TVC Collection Indonesia pada tanggal 17 April 2016 dan telah ditonton lebih dari 600 ribu penonton serta memiliki 84 komentar, salah satu dari komentar tersebut menyatakam bahwa pemeran iklan adalah orang Filipina dan Latin. Secara tidak langsung kalimat tersebut menyatakan bahwa perempuan Indonesia tidak semenarik seperti yang ditampilkan dalam iklan. Berangkat dari fenomena tersebut, penelitian ini adalah representasi stereotip pada perempuan berkulit gelap dalam iklan Fair and Lovely.

Iklan Pond's White Beauty versi Gita Gutawa yang bertema cantik putih merona seperti orang Korea menciptakan konflik budaya dalam hal makna kecantikan bagi perempuan Indonesia. Hal ini dibuktikan dengan melakukan analisis semiotik pada iklan Pond's White Beauty dengan metode semiotik Pierce. Melalui analisis semiotik, iklan Pond's White Beauty menampilkan stereotip mengenai gambaran kecantikan bagi perempuan Indonesia. Perempuan yang cantik merupakan perempuan yang putih seperti orang Korea padahal bagi orang Indonesia yang memiliki genetik berbeda, hal ini menjadi tolak ukur yang tidak dapat disamakan (Sari, 2015).

Iklan Pond's ini menyajikan kesadaran palsu, dimana perempuan Indonesia dapat memiliki kulit putih seperti Korea hanya dengan menggunakan produk Pond's. Berdasarkan analisis Marxist dapat dilihat bahwa iklan Pond's ini dibuat untuk kepentingan kaum kapitalis, yang dalam hal ini produsen produk yaitu Unilever. Unilever sebagai kapitalis menghegomoni para perempuan Indonesia untuk membeli produk kecantikan Pond's dengan menggunakan media iklan untuk menciptakan kesadaran palsu dalam pikiran para perempuan Indonesia tentang gambaran kecantikan. Berbeda dengan penelitian Wulan Purnama Sari di atas, penelitian ini menggunakan obyek penelitian yang berbeda. 
Jika Wulan Purnama Sari meneliti iklan Pond's, maka penelitian ini mengangkat tentang iklan Fair and Lovely (Sari, 2015).

\section{KAJIAN PUSTAKA}

\section{REPRESENTASI}

Representasi adalah serangkaian proses yang menandakan praktik-praktik penggambarkan objek atau praktik lain di dunia 'nyata'. Representasi merupakan tindakan dari simbolisme yang mencerminkan dunia objek independen. Namun, untuk studi budaya, representasi tidak hanya mencerminkan dalam bentuk simbolis 'hal' yang ada dalam sebuah dunia objek independen, lebih tepatnya, representasi bersifat konstitutif dari artinya dari apa yang mereka maksudkan untuk bertahan. Artinya, representasi tidak melibatkan korespondensi antara tanda dan objek tetapi menciptakan 'efek representasional' realisme (Barker, 2004). Berdasarkan konsep di atas jika dikaitkan dengan perempuan maka bisa diasumsikan kulit putih perempuan adalah bentuk definisi dari berbagai kepentingan, contohnya model iklan perempuan dalam iklan. Pada dasarnya model tersebut tidak mendefinisikan dirinya sendiri, melainkan mendefinisikan kepentingan pengiklan, mendefinisikan situasi serta pihak lain yang ikut serta di balik layar terbentuknya sebuah iklan.

\section{IKLAN}

Iklan merupakan sarana untuk mempromosikan suatu produk yang ditujukan kepada calon konsumen atau masyarakat. Iklan yang baik adalah iklan yang mampu mendorong konsumennya untuk membeli produk yang dipromosikan dan sekaligus berhasil membentuk persepsi merek yang kuat dalam bemak target konsumen (Agung, 2003). Sebuah iklan yang dipasang pasti memiliki tujuan dan mengharapkan umpan balik dari masyarakat, serta iklan yang efektif adalah iklan yang mampu membangun persepsi masyarakat yang baik terhadap iklan.

Iklan seharusnya menjadi sarana yang baik untuk menyampaikan informasi sebuah produk kepada masyarakat, bukan untuk ajang bersaing dengan kompetitor. Banyak iklan saat ini yang memunculkan persepsi dalam masyarakat, seperti iklan Fair and Lovely mempertontonkan seluruh tubuh yang memiliki kulit halus sebagai standar kecantikan untuk kaum perempuan pada umumnya, iklan Fair and Lovely sendiri mengiklankan produknya melalui saluran televisi.

Televisi adalah sebuah media telekomunikasi yang dikenal sebagai penerima siaran gambar bergerak beserta suara, baik itu yang monokrom (hitam putih) maupun warna. Televisi merupakan media paling berpengaruh dalam kehidupan manusia, hal ini disebabkan oleh pesatnya perkembangan televisi yang menjangkau masyarakat hingga ke wilayah terpencil. Unsur esensial dari televisi berupa penggunaan bahasa verbal dan visual, sekaligus dalam rangka menyampaikan sesuatu seperti pesan, informasi, pelajaran, ilmu, dan hiburan sehingga, sajian dalam bahasa audio visual lebih mudah diingat daripada yang ditulis dan dibaca. Penampilan perempuan memiliki daya tarik yang tinggi, karena itulah dari segi bisnis memiliki harga jual yang tinggi juga. Perempuan tidak lagi dinilai dari segi kapasitas intelektual atau kualitas spiritualnya, tetapi lebih kepada materi atau penampilan luarnya. Perempuan selalu memeriahkan jagat periklanan baik melalui media cetak maupun media elektronik.

Kehadiran sosok perempuan menjadi bumbu penyedap dalam media massa. Saat ini, ketika karyakarya seni kreatif seperti iklan menjadi konsumsi masyarakat dalam berbagai media massa, posisi perempuan ini menjadi sangat potensial untuk dikomersialkan dan dieksploitasi, karena posisi perempuan menjadi sumber inspirasi dan juga tambang uang yang tak habis-habis (Burhan Bungin, 2003).

\section{FAIR AND LOVELY}

Fair \& Lovely merupakan sebuah brand pelopor perawatan kulit wajah wanita di dunia yang diproduksi pertama kali di Mumbai, India. Fiar and Lovely sendiri adalah krim pencerah kulit secara instan, menghilangkan noda bekas jerawat, mengurangi noda hitam, dan juga mengurangi efek 
penggelapan wajah. Seiring berjalannya waktu, Fair and Lovely tidak hanya memproduksi krim pemutih wajah saja. Di tahun 2016, merek tersebut membuat produk baru bernama Fair and Lovely Multivitamin Facial Foam, produk tersebut diyakini dapat membantu mengangkat kotoran di wajah secara lembut agar wajah bersih cerah seketika. Perubahan warna kulit dari gelap keterang diyakini dapat terlihat diawal pemakaian, dalam proses pembelajarannya Fair and Lovely menggambarkan ikon profil mereka seperti Jessica mila. Jessica Mila bukanlah satu-satunya model yang dalam iklan Fair and Lovely, ada bintang lainnya seperti Shireen Sungkar.

\section{STEREOTIP}

Stereotip merupan penilaian bias yang dilakukan oleh individu, grup, atau ide. Syarat diterapkan biasanya untuk menggambarkan harapan yang dimiliki orang orang lain menurut usia, jenis kelamin, penampilan fisik, kelompok etnis, ras, atau pekerjaan. Stereotip adalah penilaian yang terlalu disederhanakan diterapkan sebagai generalisasi, merupakan suatu bentuk prasangka bias (Danesi, 2014). "Kulit putih" adalah kata yang paling diharapkan oleh semua perempuan manapun, semua perempuan akan sangat berharap dirinya memiliki kulit putih dan dikagumi banyak orang. Kata "kulit putih" telah dibentuk oleh media di dalam benak masyarakat secara sadar baik melalui iklan maupun tayangan-tayangan sinetron. Stereotip ini dibentuk dan menjadi pemisah untuk perempuan "kulit putih" dan "kulit gelap" begitu pula dengan iklan-iklan Indonesia. karena definisi "kulit putih" ini membuat perempuan berlomba-lomba merombak dirinya dengan memakai berbagai produk pemutih, bahkan mereka rela melakukan suntikan pemutih maupun apa saja termasuk meronggoh kocek dalamdalam ke klinik demi mendapatkan pujian "kulit kamu putih ya."

\section{SEMIOTIKA}

Pendekatan semiotik untuk representasi tergantung pada gagasan bahwa semua menggunakan bahasa dimulai dengan tanda. Semiotika, atau 'ilmu tentang tanda', adalah disiplin yang mengembangkan pengetahuan tentang cara mengambil benda individu pada makna (Webb, 2008). Bukan hal baru bahwa perempuan kerap ditampilkan dalam sebuah iklan, citra perempuan dalam iklan Fair and Lovely dapat dikategorikan sebagai citra Pigura, menggambarkan perempuan sebagai makhluk yang memikat perempuan dalam iklan tersebut tampil memikat, kulit lebih putih, halus, dan cerah setelah menggunakan Fair and Lovely. Citra yang kedua yakni pergaulan, menggambarkan perempuan sebagai makhluk yang dipenuhi kekhawatiran karena tidak tampil memikat dan menawan.

\section{METODE PENELITIAN}

Model penelitian yang dipakai dalam penelitian ini adalah deskriptif kualitatif dengan paradigma kritis. Secara lebih operasional, penelitian ini menggunakan metode semiotika untuk menganalisis obyek penelitian. Obyek penelitian dalam penelitian ini adalah iklan Fair and Lovely, iklan yang berdurasi 0.30 detik tersebut telah diunggah ulang oleh akun Youtube TVC Collection Indonesia pada tanggal 17 April 2016 dan telah ditonton lebih dari 600 ribu penonton serta memiliki 84 komentar. Obyek penelitian ini dianalisis dengan menggunakan analisis semiotika Roland Barthes yang mengembangkan pemikiran dari Ferdinand De Saussure. Semiotika berasal dari Bahasa Yunani, semieon yang berarti tanda. Semiotika diperkenalkan oleh Ferdinand De Saussure (1857-1913). Untuk memahami gagasan Saussure, kita perlu memahami tentang penanda dan petanda, serta langue dan parole.

Pertama, tanda (sign) terdiri dari dua aspek, yaitu penanda (signifiant), dan petanda (signified). Penanda dapat dimengerti sebagai bentuk/wujud fisik. Penanda bisa berupa bunyi, gambar, huruf, visual dan sejenisnya. Sedangkan petanda adalah konsep atau arti dari apa yang ditandai. Relasinya antara keduanya bersifat "diada-adakan" (arbitrary), yang berarti tidak ada relasi yang sifatnya alamiah antara penanda dan petanda. Namun demikian, relasi yang bersifat "diada-adakan” terikat oleh konvensi atau struktur. Penjelasan selanjutnya akan menjelaskan tentang hal ini. Secara etimologis, 
Saussure menyebutkan bahwa semiotika sebagai ilmu yang mengkaji tentang tanda sebagai bagian dari kehidupan sosial (Piliang, 2003). Selanjutnya Saussure, semiotika kemudian dielaborasi sebagai hubungan tripartit yakni tanda (sign) yang merupakan gabungan dari penanda (signifier) dan petanda (signified) (Fiske dan Hartley, 1996. Kedua, langue dan parole. Langue merupakan abstraksi dan artikulasi bahasa pada tingkat sosial budaya, sedangkan parole merupakan ekspresi bahasa pada tingkat individu. Langue bisa kita sebut sebagai sistem bahasa yang berlaku, sedangkan parole adalah bagaimana individu berbahasa dalam sistem tersebut.

Roland Barthes melanjutkan pemikiran Saussure dengan memberi telaah pada interaksi antara teks dengan pengalaman personal dan kultural penggunanya. Interaksi antara konvensi dalam teks dengan konvensi yang dialami dan diharapkan oleh penggunanya. Gagasan Barthes ini dikenal dengan tatanan penandaan (order of signification), yang mencakup primary signification atau denotasi (makna sebenarnya sesuai kamus) dan secondary signification atau konotasi (makna ganda yang lahir dari pengalaman kultural dan personal). Makna konotasi inilah yang kemudian menjadi berkembang menjadi mitos. Dalam penelitian ini, penulis berusaha melakukan analisis semiotika, mulai dari primary signification sampai secondary signification pada iklan Fair and Lovely.

\section{HASIL DAN PEMBAHASAN}

\section{KULIT PUTIH SEBAGAI STANDAR KECANTIKAN WANITA DI INDONESIA}

Penggunaan perempuan dalam iklan tak semata-mata mengiklankan suatu produk atau layanan, tapi juga diarahkan untuk menciptakan nilai atau citra produk. Upaya-upaya membentuk citra produk ini seringkali menggunakan tanda atau bahasa yang menyentuh bias gender dalam masyarakat. Bias gender tersebut menyangkut penggunaan figur perempuan sebagai objek tanda (Siswanti, 2014).

Penggunaan perempuan dalam iklan bisa menambah daya tarik khalayak untuk menikmati pesan iklan. Perempuan adalah bumbu dari sebuah iklan, iklan dipercaya akan mampu mendapatkan pengaruh besar jika menggunakan perempuan sebagai salah satu ilustrasi atau modelnya (Widyatama, 2007). Saat ini bisa dilihat bahwa para perempuan menghabiskan banyak uang untuk perawatan kulit. Bahkan, tak sedikit perempuan menyediakan dana khusus rutin setiap bulan untuk perawatan, kulit putih menjadi hal penting bagi perempuan mana pun, dalam hal ini, warna kulit menjadi salah satu aspek paling penting untuk dibicarakan. Perempuan sekarang ingin selalu memiliki kulit putih, bersih, halus, bahkan bercahaya, seperti yang terlihat dari para model iklan kecantikan di televisi yang tampak cantik, putih, bersih, dan bersinar.

Bahkan, banyak yang tak peduli bagaimana karakter dan warna asli kulit mereka yang sebenarnya berbeda dengan apa yang ditunjukkan model iklan. Di sini, kita mulai melihat bagaimana iklan memengaruhi perempuan dalam memandang kecantikan kulit. Bahwa perempuan yang cantik adalah yang berkulit putih, mulus, dan bercahaya. Seakan-akan, perempuan yang memiliki karakter warna kulit berbeda tak berkesempatan menjadi cantik. Perempuan merupakan salah satu bagian terpenting dalam pembuatan iklan Fair and Lovely. Pesona perempuan dalam iklan Fair and Lovely ini dipergunakan supaya iklan lebih menarik dan mudah di ingat oleh siapapun yang melihatnya. Iklan Fair and Lovely menggunakan model perempuan karena perempuan dipandang sebagai suatu bentuk keindahan. 


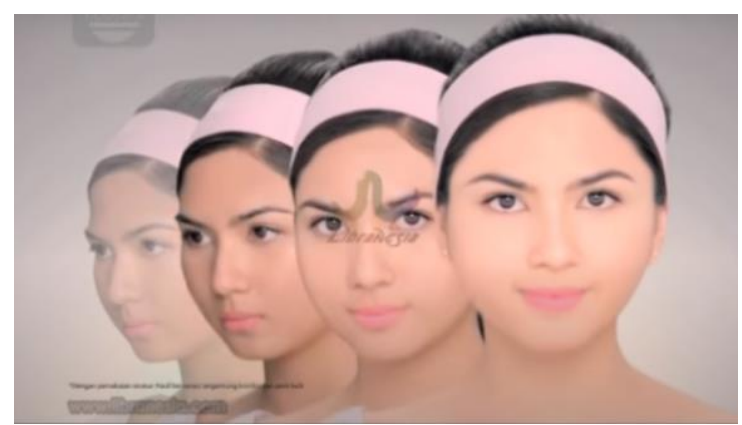

Gambar 1. Iklan Fair and Lovely

Gambar model pada iklan Fair and Lovely dapat dilihat bahwa raut wajah model tersebut menunjukan keadaan emosi pada saat terjebak ketika memiliki kulit wajah kusam dan berubah menjadi cerak seketika, yang awalnya muram menjadi senyum. Bila diamati lebih dalam lagi Iklan Fair and Lovely sangat berperan dalam mengkonsepkan pola pikir dan pola perilaku masyarakat. Kehadiran perempuan dalam iklan produk perawatan wajah juga turut serta di tampilkan dengan maksud untuk mendukung proses persuasif yang dikehendaki oleh produsen, dalam hal ini produsen menggunakan cara untuk memasarkan produk pada satu sisi berusaha 'tampil beda' agar menarik tetapi pada sisi lain mengekalkan stereotip.

Hal ini selaras dengan Representasi wanita di media, bagaimana media menampilkan sosok wanita sering kali menjadi acuan dan contoh yang digunakan untuk menilai wanita pada umumnya. Bukan hanya mereka yang berlainan gender terhadap wanita, tetapi juga wanita melihat diri mereka sendiri dan melihat sesama wanita lainnya. Dunia saat ini telah dipenuhi oleh media, saluran televisi dan stasiun radio hampir tak terhitung jumlahnya

Bahkan kehadiran perempuan cantik dalam media massa seringkali dijadikan acuan bagaimana seorang perempuan mempresentasikan dirinya dihadapan publik. Oleh karena itu, ada transmisi pemikiran dan konsepsi yang diterima masyarakat. Iklan merepresentasikan soal "bagaimana itu cantik" kepada masayrakat secara tidak sadar masyarakat diberikan pola pikir bahwa perempuan berkulit gelap itu tidak cantik. Selain dari kecantikan, feminitas juga dianggap sebagai bagian dari kecantikan seorang perempuan. Hal tersebut tampak dari iklan yang menampilkan perempuan dalam sikap lemah lembut, ramah. Penampilan adalah salah satu kunci dari feminitas saat ini perempuan harus cantik, langsing, putih, dan berpakaian baik untuk menjadi sosok yang diinginkan oleh orang lain.

\section{STEREOTIPE MEDIA TEHADAP PEREMPUAN BERKULIT GELAP}

Media sendiri mempunyai peran yang besar dalam pembentukan stereotipe atas warna kulit perempuan. Kecantikan menurut media selalu dicirikan dengan tampilan fisik yang sangat menarik, hal itu diwujudkan dalam bentuk kulit putih bersinar. Jika seorang perempuan cantik dan memiliki kulit putih serta langsing, hal ini tercermin pada gambar yang ada di dalam iklan Fair and Lovely dimana seorang perempuan berkulit putih memperkenalkan Fair and Lovely sehingga enam orang perempuan tersebut sepertinya ingin memiliki kulit wajah yang cerah agar percaya diri dan mempunyai daya tarik tersendiri.

Efek media juga akan semakin lebih kuat karena sosok perempuan yang ditampilkannya adalah salah satu cara untuk memperkokoh stereotipe yang sudah terbangun di tengah masyarakat. Oleh karena itu mengapa media ikut serta memperkokoh, melestarikan, bahkan memperburuk ketidakadilan terhadap perempuan di tengah masyarakat. Ketika sebuah media massa menyajikan sebuah fakta tentang perempuan secara konsisten, masyarakat akan menyangka bahwa tindakan paling tepat atau logis adalah mempercayai apa yang dikatakan oleh media. 
Dalam media, perempuan yang cantik selalu diidentikkan dengan kulit putih, berambut lurus dan panjang, bertubuh langsing, karena hal tersebut dianggap pilihan paling ideal dalam kehidupan bermasyarakat. Media secara perlahan akan menguatkan stereotipe tersebut. Hal ini mengakibatkan timbulnya anggapan bahwa kekuatan utama dari seorang perempuan adalah warna kultnya, bukan faktor yang lain seperti keunggulan intelektual, keluasan wawasan, da lain sebagainya.

\section{SEMIOTIKA IKON PEREMPUAN PADA IKLAN FAIR AND LOVELY}

Pada dasarnya perempuan dalam iklan dapat dilihat melalui interaksi dinamis yang berlangsung antara iklan, media serta perempuan sebagai model atau pelaku iklan, sebuah analogi antara sosok iklan di media yang direpresentasikan melalui tampilan iklan dibandingkan dengan realitas yang cenderung dibangun atas realitasnya sendiri, dari eksplorasi terhadap kebutuhan perempuan sebagai subjek dan objek periklanan (Mukti, 2015).

Tanda-tanda konotasi pada iklan Fair and Lovely adalah Kulit wajah cerah merona merupakan warna kulit yang diinginkan oleh perempuan. Iklan Fair and Lovely menjadi objek penelitian karena iklan tersebut menawarkan produknya melalui pesan, biasanya berupa simbol-simbol yang disisipkan dalam gambar atau kata yang disisipkan ke dalam naskah iklan atau lirik jingle iklan. Hal tersebut terlihat di dalam iklan, tentang persepsi masyarakat akan perempuan cantik. Kulit putih merupakan subliminal pesan yang disampaikan kepada masyarakat yang kemudian mempersuasi alam bawah sadar masyarakat sehingga penilaian masyarakat akan perempuan yang cantik adalah perempuan berkulit putih. Ini merupakan bentuk penjajahan ras dan status sosial, dalam hal ini, iklan menunjukkan bahwa perempuan berkulit putih lebih cantik dibandingkan dengan perempuan berkulit hitam Kecantikan adalah perempuan berkulit putih.

Kulit yang kusam merupakan sebuah kejelekan dan maka itu haruslah dirubah. Kekecewaan perempuan yang timbul jika memiliki kulit yang kusan dan tidak bersinar. Kebahagiaan yang paling menyenangkan dari seorang perempuan adalah ketika mempunyai kulit segar cerah merona, merupakan kecantikan sempurna, selain itu petanda yang ada dalam iklan Fair and Lovely yakni ekspresi kegembiraan dari model ditambah dengan penonjolan pada kulit sang model yang awalnya berwarna cokelat kusam kemudian berangsur-angsur berubah menjadi putih bersinar kemudian menujukkan kulitnya yakni kulit putih sedikit fair diiringi monolog "wajah bersih cerah seketika."

Hal ini iklan Fair and Lovely menargetkan konsumen dengan seorang perempuan aktif yang jarang sekali memiliki waktu luang yang panjang teruntuk para remaja, khususnya remaja Indoneia yang ingin memiliki kulit cantik dan terlihat putih alami. Bahkan perempuan yang kini banyak berperan sebagai perempuan karier merupakan target pasar tersendiri bagi produsen, yang tentunya memerlukan pendekatan iklan yang berbeda dengan perempuan yang tidak bekerja. Iklan dituntut untuk mengikuti perubahan dalam masyarakat, jika tidak maka iklan tidak akan mengenai targetnya dan gagal. Penargetan ini dapat kita lihat dari iklan-iklan produk Fair and Lovely yang selalu menggunakan bintang-bintang muda seperti Jessica Mila dan bintang-bintang lainnya.

Kekuatan iklan dalam menghasilkan produk pencitraan telah ikut andil dalam menyuburkan stereotipe yang selama ini dilekatkan pada perempuan. Simbol-simbol sosial yang selama ini dilekatkan pada wanita kemudian diolah lebih jauh secara kreatif oleh para pembuat iklan untuk lebih mendekatkan produk yang akan ditawarkan dengan kemauan konsumen. Produk-produk yang ditawarkan berupa sabun dan lainnya selalu menggunakan ikon wanita sebagai alat jual yang cukup signifikan (Astuti, 2016).

\section{KESIMPULAN}

Iklan digunakan sebagai media untuk mengkomunikasikan dan menarik perhatian sebagian atau seluruh lapisan masyarakat untuk merespon suatu barang atau jasa yang dikomunikasikan. Untuk itu, tak jarang beberapa iklan memang berlomba-lomba menggunakan ide semenarik mungkin untuk konsumen nya. Salah satu cara yang digunakan adalah dengan menggunakan model wanita yang 
menampilkan kulit putih menunjukkan sisi kecantikan ideal sebagai objek agar mendapat nilai lebih di masyarakat. Di Indonesia, perempuan dipersepsikan cantik ketika mereka dinilai 'enak dipandang mata', 'indah', atau bahasa anak zaman sekarang: 'bening'. Cirinya bisa bermacam-macam: tinggi, langsing, berambut panjang, atau berisi. Semua bisa, tergantung pada 'selera'-biasanya selera lakilaki-masyarakat yang berlaku. Tapi, terutama di Indonesia, yang pasti dan jamak selalu harus ada pada diri mereka adalah: berkulit putih. Salah satu iklan yang menerapkan hal tersebut adalah Iklan facial wash Fair and Lovely. Iklan tersebut dianggap pembentukan stereotipe atas warna kulit perempuan di Indonesia, dalam iklan ini juga merepresentasikan seolah-olah perempuan yang memiliki kulit gelap merupakan sebuah kejelekan dan maka itu haruslah dirubah sehingga kecantikan yang dimaksud dalam iklan tersebut selalu dicirikan dengan tampilan fisik yang sangat menarik, hal itu diwujudkan dalam bentuk kulit putih bersinar.

\section{REFERENSI}

Agung, Yuliana. 2003. 101 Konsultasi Praktis Pemasaran. Jakarta: Elex Media Komputindo

Astuti, Y. D. (2016). Media dan Gender (Studi Deskriptif Representasi Stereotipe Perempuan dalam Iklan di Televisi Swasta). Profetik: Jurnal Komunikasi, 9(2), 25-32.

Barker, C. (2004). The Sage dictionary of cultural studies. USA: Sage.

Bungin, Burhan. 2003. Analisis Data Penelitian Kualitatif: Pemahaman Filosifis dan Metodologis ke Arah Penguasaan Model Aplikasi. Jakarta: Raja Grafindo Persada

Danesi, M. (2014). Dictionary of Media and Communications. UK: Routledge.

Kurniadi, O. (2007). Perempuan dalam Tayangan Iklan di Televisi. Mediator: Jurnal Ilmu Komunikasi, 8(1). doi: https://doi.org/10.29313/mediator.v8i1.1230

Kusumastutie, N., \& MA, F. (2015). Semiotika Untuk Analisis Gender Pada Iklan Televisi. Buletin Psikologi, 12(2).doi:http://dx.doi.org/10.22146/bpsi.7473s

Mukti, I., \& MI, S (2015). Semiotika Ikon Perempuan Pada Iklan Mobil dalam Majalah Otomotif Autoexpert. Jurnal Komunikasi KAREBA, 4(3). doi: https://doi.org/10.31947/kjik.v4i3.631

Saraswati, A. (2017). Putih: Warna Kulit, Ras, dan Kecantikan di Indonesia Transnasional. Tangerang: Marjin Kiri.

Sari, W. (2016). Konflik Budaya Dalam Konstruksi Kecantikan Wanita Indonesia (Analisis Semiotika dan Marxist Iklan Pond's White Beauty Versi Gita Gutawa). Jurnal Komunikasi, 7(2), 198-206. doi:http://dx.doi.org/10.24912/jk.v7i2.18

Siswati, E. (2014). Representasi Domestikasi Perempuan dalam Iklan. Jurnal Ilmu Komunikasi, 11 (2). doi: https://doi.org/10.24002/jik.v1 1i2.417

Watie, E. (2016). Representasi Wanita Dalam Media Massa Masa Kini. Jurnal the Messenger, 2(2), 110. doi:http://dx.doi.org/10.26623/themessenger.v2i2.297

Webb, J. (2008). Understanding Representation. USA: Sage.

Wicaksono, I. P. (2013). Representasi Eksploitasi Perempuan dalam Iklan. Jurnal Ilmu Komunikasi, 9(2), 149-167. https://doi.org/10.24002/jik.v9i2.171 